\title{
Non-Hereditary Clear Cell Renal Cell Carcinoma
}

National Cancer Institute

\section{Source}

National Cancer Institute. Non-Hereditary Clear Cell Renal Cell Carcinoma. NCI

Thesaurus. Code C36261.

The most common type of renal cell carcinoma, characterized by a loss of genetic material of the short arm of chromosome 3. The most common symptom at the time of diagnosis is hematuria. The tumor has a golden-yellow color because of the abundance of intracytoplasmic lipid. This is a clinically aggressive type of renal cell carcinoma. The tumor usually metastasizes to unusual sites and late metastasis is common. 